\title{
Milk flow, teat morphology and subclinical mastitis prevalence in Gir cows
}

\author{
Marco Aurélio de Felicio Porcionato(1), Weber Vilas Boas Soares(2), Carolina Barbosa Malek dos Reis ${ }^{(1)}$, \\ Cristina Simões Cortinhas ${ }^{(1)}$, Lucinéia Mestieri(1) and Marcos Veiga dos Santos ${ }^{(1)}$
}

\begin{abstract}
(1)Universidade de São Paulo, Faculdade de Medicina Veterinária e Zootecnia, Departamento de Nutrição e Produção Animal, Avenida Duque de Caxias Norte, № 225, CEP 13635-900 Pirassununga, SP, Brazil. E-mail: mafporcionato@usp.br, carolmalek@usp.br, ccortinhas@usp.br, mestieri@usp.br, mveiga@usp.br (2)Agência Paulista de Tecnologia dos Agronegócios, Instituto de Ciência Animal, Avenida Presidente Castelo Branco, s/no CEP 13730-970 Mococa, SP, Brazil. E-mail: webervbs@yahoo.com.br
\end{abstract}

\begin{abstract}
The aim of this work was to evaluate the association between milk flow, teat morphological measurements and subclinical mastitis prevalence in Gir cows. Eighty cows in the $2^{\text {nd }}$ and $3^{\text {rd }}$ lactations, with 90 to 200 days of lactation, were divided according to milk flow during milking into fast or slow groups. Teat morphometry was assessed by ultrasound scanning of the right anterior teat and external measurements. Milk samples were collected for somatic cells count (SCC) and microbiological culture. The effect of milk flow during milking was evaluated by analysis of variance of milk yield, SCC, morphometry and external measurements. The association of morphometry and external measurements of the teats with the SCC and microorganisms found in milk were analysed. Milk flow was significantly correlated to milk production. Gir cows with slower milk flow had longer teat canal and greater milk yield, in comparison to cows with fast milk flow. Teat-end to floor distance influenced SCC of Gir cows. Prevalence of subclinical mastitis and the type of mastitis-causing pathogens were not affected by milk flow during milking.
\end{abstract}

Index terms: Gir, lactation, mammary gland, milking, morphology.

\section{Fluxo de leite, morfometria de tetos e a prevalência de mastite subclínica em vacas Gir}

Resumo - O objetivo deste trabalho foi avaliar a associação entre o fluxo de leite, a morfometria dos tetos e a prevalência de mastite subclínica em vacas Gir. Oitenta vacas em 2 $2^{\mathrm{a}}$ ou $3^{\mathrm{a}}$ lactação, com 90 a 200 dias de lactação, foram divididas, de acordo com o fluxo de leite durante a ordenha, nos grupos rápido ou lento. A morfometria de tetos foi avaliada por imagens de ultrassom do teto anterior direito e medidas externas dos tetos. Amostras de leite foram coletadas para a contagem de células somáticas (SCC) e a cultura microbiológica. O efeito do fluxo de leite durante a ordenha foi avaliado pela análise de variância de produção de leite, SCC, morfometria e medidas externas dos tetos. Foi analizada a associação entre a morfometria e medidas externas dos tetos e a SCC e microganismos encontrados no leite. O fluxo de leite foi significativamente correlacionado à produção de leite. As vacas Gir com fluxo de leite mais lento tinham maior comprimento de canal dos tetos e maior produção de leite, em comparação a vacas de fluxo rápido. A distância do teto ao solo influenciou a SCC das vacas Gir. A prevalência de mastite subclínica e o tipo de microrganismo causador de mastite não foram alterados pelo fluxo de leite durante a ordenha.

Termos para indexação: Gir, lactação, glândula mamária, ordenha, morfologia.

\section{Introduction}

Among dairy breeds, Gir cows represent an important percentage of Brazilian dairy cattle herd mainly because of its high adaptability to the tropical climate and the production systems. The morphophysiologic characteristics - capacity and udder support, pigment of external layer, thermoregulatory capacity, aplomb and strong feet, good feed conversion and reproductive efficiency - allow of a satisfactory performance as a pure breed or as crossbred with European breeds to improve the productive performance in the tropical areas (Souza et al., 1996; Madalena \& Trivedi, 1998).

The studies of milk flow patterns provide important information about the cow's responses to milking in different situations, such as the udder health state (Pérez-Guzman et al., 1986; Naumann et al., 1998) and the inefficiency in milk ejection (Tancin \& Bruckmaier, 2001).

Tancin et al. (2007) studied the milk flow and its variations during lactation and observed influences in the somatic cell counts (SCC), as much as the udder

Pesq. agropec. bras., Brasília, v.45, n.12, p.1507-1512, dez. 2010 
as the individual teats. Generally, a SCC threshold of 200,000 cells $\mathrm{mL}^{-1}$ are recommended as the limit to separate uninfected mammary quarters from the infected ones, to decrease the occurrence of false-negative and false-positive results (Schepers et al., 1997; Djabri et al., 2002). Using 200,000 cells $\mathrm{mL}^{-1}$ SCC threshold, Schepers et al. (1997) found 74\% sensitivity and $89 \%$ specificity in Holstein cows. Anatomical characteristics of teats have positive correlation with milk flow rate during milking that could be used for precocious identification of udder health problems which could increase the risks of mastitis (Tancin et al., 2007).

According to Norman et al. (1988), anatomical characteristics of dairy cattle are not equal for all breeds, in a way that the udder and teat morphology could favor an individual performance or a determined breed. Due to these differences, some anatomical measurements of mammary glands, obtained by ultrasound, have been used in research with dairy herds (Bruckmaier \& Blum, 1992; Ayadi et al., 2003). The ultrasonography technique used for udder and teat cisterns studies appears as a minimally invasive tool (Porcionato et al., 2005) and result in important information for genetic selection, for supporting the decision of adequate management to be adopted (Schutz \& Pajor, 2001) and for mastitis prevention (Klein et al., 2005). Udder depth and teat length measurements have a narrow relation with mastitis resistance (Klein et al., 2005).

The studied hypothesis was that the teat morphology of Gir cows influences the prevalence of subclinical mastitis.

The objective of this work were to evaluate the association between teat morphology and milk flow during milkings and prevalence of subclinical mastitis in Gir cows.

\section{Materials and Methods}

The experiment was carried out at Instituto de Ciência Animal (IZ/APTA), Mococa, São Paulo state, Brazil, and at Empresa de Pesquisa Agropecuária de Minas Gerais (Epamig), Uberaba, Minas Gerais state, Brazil. Experimental procedures were approved by the Institutional Animal Care and Use Committee, Memphis, USA. Eighty Gir cows were used as experimental animals, with second or third lactation, averaging milk yield of $7.2 \pm 0.3 \mathrm{~kg}$ per day and between
90 to 200 days in milking, were sampled during eight months, in the total of 640 measurements.

Cows were sorted according to the milking time and milk yield, divided into two groups according to the speed of milking: fast flow (FF) and slow flow (SF). Cows with milk flow greater then the average milk flow in all animals of $26.3 \mathrm{~mL} \mathrm{~s}^{-1}$ of milk, were assigned for the fast flow group, while lower-milk flow animals were considered for the slow-flow group.

Cows were handled in tropical pastures, with free access to water, and fed a concentrate according to their state of lactation. Milking was carried out at $6 \mathrm{~h}$ and $16 \mathrm{~h}$, following the standard sequence of procedures: calves stimuli, strip cup test for clinical mastitis diagnosis, pre-dipping, drying of teats with paper towel, teat cups attachment, withdrawal after milk flow end, and post-dipping. Before the onset of milking, cows were kept in a shaded waiting area with natural ventilation. A tandem parlor with six stalls at each side of the pit was used. The following milking machine parameters were constantly set throughout the experiment: vacuum $45 \mathrm{kPa}$, pulsation ratio $60: 40$ and pulsation rate $60 \mathrm{c} \mathrm{min}^{-1}$. Temperature and relative humidity were monitored on the days of measurements, remaining in the range considered of thermal comfort for dairy cows (temperature humidity index $(\mathrm{THI})<72$ ) according to Silva et al. (2009).

Individual milk yield and milk flow were monthly measured and milk samples were collected monthly from all mammary quarters for somatic cell counts (SCC) and microbiological culture. Cows were considered with subclinical mastitis, when SCC was above 200,000 cells $\mathrm{mL}^{-1}$ and with positive pathogen isolation (Schepers et al., 1997; Djabri et al., 2002). Clinical cases of mastitis were defined by the presence of abnormalities in milk, which were suggestive of inflammation of the mammary gland, such as flakes, clots, or other unusual aspect. These samples were not used for analysis of SCC. Samples for microbiological culture were aseptically collected during morning milking, and bacteriological procedures were performed according to the National Mastitis Council (1999). Briefly, from each sample, $0.1 \mathrm{~mL}$ of milk was plated on blood agar (one plate per cow) and incubated aerobically for 24 hours and 48 hours at $37^{\circ} \mathrm{C}$. A quarter was considered culture-positive, when growth of at least one colony was detected. Samples yielding more than two different bacterial species were 
considered to be contaminated. Bacteria were identified based on colony morphology and Gram-staining. For Gram-positive cocci, catalase tests with hydrogen peroxide $(3 \%)$ were used to differentiate between catalase-positive staphylococci and catalase-negative cocci. Coagulase test was carried out using sterile rabbit plasma to distinguish Staphylococcus aureus (coagulase-positive) from non-aureus staphylococci, referred to as coagulase-negative staphylococci. Streptococci were subdivided into aesculin-positive cocci and aesculin-negative cocci (Streptococcus agalactiae and Streptococcus dysgalactiae). CAMP-test was used to differentiate $S$. agalactiae from $S$. dysgalactiae. Cultures with more than one species of bacterium isolated were excluded from data analysis.

Ultrasound technique was based on procedures described by Porcionato et al. (2009). Ultrasound images were only obtained in the right anterior mammary gland, as Ayadi et al. (2003), which showed a high correlation between measurements taken in the four glands and teats. The calves of Gir cows were prevented from sucking on the anterior right teat prior to ultrasound measurements. Images were scanned using an ultrasound DP 2200VET (Mindray, Shenzhen, China), with a linear transducer $(3.5 \mathrm{MHz})$ cranially positioned directed to the teat. The teats were submerged in a water-filled recipient during the ultrasound scanning, according to Porcionato et al. (2009).

In order to obtain sharper images, the way of contact for ultrasound transmission was in the form of gel Carbogel ULT (Carbogel Ind. e Com. Ltda, São Paulo, SP, Brazil) between the transducer and the water-filled recipient. The measurements of the teat parameters taken from ultrasound images were analyzed in duplicate using Eview software, Echo Image Viewer, version 1.0 (Pie Medical, Indianapolis, IN, USA).

The teat morphometry of Gir cows was evaluated by external measurements of conformation: teat-end to floor was considered the distance $(\mathrm{cm})$ between the teat-end and the floor, forming an angle of $90^{\circ}$ with the floor measured with a tape measure. Teat length was considered the distance $(\mathrm{cm})$ between the teat insertion in the udder and the teat-end measured with a tape measure. Teat diameter was measured in the middle of the teat with a caliper.
The experimental design was completely randomized, with two groups according to milk flow (fast or slow) evaluated during eight months of lactation. The effect of teat morphology on SCC and on pathogen type was evaluated. The PROC GLM (SAS Institute, 2001) was used for data analysis of variance by means of ANOVA, based on GLM models. Effects were separated by Tukey test. All values were given as the mean \pm one standard error of the mean (SEM). The relationship between morphological characteristics of teats, SCC and pathogen type was evaluated by Pearson correlation coefficients. Significance level was stated at $5 \%$ probability.

\section{Results and Discussion}

There were significant differences between groups for milk yield and teat canal length $(\mathrm{p}<0.05)$ (Table 1). In cows with fast milk flow, teat canal lengths were smaller. Milk flow was significantly correlated with milk yield $(\mathrm{r}=0.53, \mathrm{p}<0.001)$. There was no difference in teat wall thickness between groups, but the correlation with the teat canal length was positive $(\mathrm{r}=0.38, \mathrm{p}<0.001)$. The other correlations between milk yield characteristics and teat morphometry were not significant.

There was a negative correlation between SCC and teat-end to floor distance $(\mathrm{r}=-0.34, \mathrm{p}<0.001)$. However, there was no significant correlation $(\mathrm{p}>0.05)$ with the other morphological parameters.

Some authors observed that teat length and diameter have an important role in mastitis prevention, since the greater the teat canal length is, the more pronounced will be the cap of keratin which acts as a natural barrier, preventing teat contamination against mastitis-causing pathogens (Paulrud \& Rasmussen, 2004; Klein et al., 2005). These authors suggest that the teat characteristics of Gir cows are related to higher

Table 1. Means \pm standard error of milk yield, milk flow, canal length and wall thickness of the teats of Gir cows according to milk flow: fast ( $\mathrm{FF}>26.3 \mathrm{~mL} \mathrm{~s}^{-1}$ ) or slow $\left(\mathrm{SF}<26.3 \mathrm{~mL} \mathrm{~s}^{-1}\right)$.

\begin{tabular}{lcrrc}
\hline Parameters & Units & \multicolumn{1}{c}{ FF } & \multicolumn{1}{c}{ SF } & \multicolumn{1}{c}{ P } \\
\hline Milk yield & $\left(\mathrm{L} \mathrm{day}^{-1}\right)$ & $7.97 \pm 0.09$ & $6.03 \pm 0.06$ & $<0.001$ \\
Milk flow & $\left(\mathrm{mL} \mathrm{s}^{-1}\right)$ & $37.88 \pm 0.62$ & $17.63 \pm 0.15$ & $<0.001$ \\
Teat canal & $(\mathrm{mm})$ & $22.31 \pm 0.14$ & $25.68 \pm 0.22$ & 0.02 \\
Teat wall thickness & $(\mathrm{mm})$ & $16.20 \pm 0.11$ & $15.38 \pm 0.12$ & 0.41 \\
\hline
\end{tabular}


natural barrier of protection against mastitis-causing agents. In the present study, the animals came from research institutes that have been implementing genetic selection programs of the herds, which may reflect in more homogeneous mammary glands and similar milk yield potential. These factors could influence teat morphology (Ayadi et al., 2003; Thomas et al., 2004).

There were no observed differences between groups $(p>0.05)$ for teat-end to floor distance and teat length and diameter (Table 2). However, negative correlations were observed between teat-end to floor distance and teat length $(\mathrm{r}=-0.38, \mathrm{p}<0.001)$ and teats diameter $(\mathrm{r}=-0.30$, $\mathrm{p}<0.001)$. Correlation was positive $(\mathrm{r}=0.70, \mathrm{p}<0.001)$ between teat length and teat diameter.

Coban et al. (2009) observed a positive, despite low correlation between teat diameter and mastitis. An increase in mastitis incidence, with an increase in teat diameter had already been observed by Chrystal et al. (1999) and Kuczaj (2003). The same authors found no correlation between teats length and SCC ( $>0.05)$. However, Shook (1989) reported that an increase in teats length also increased the predisposition of cows to mastitis.

In the literature, significant correlations between udder and teat characteristics and SCC are described. As an example, it could be mentioned the relationship

Table 2. Means ( \pm standard error) of teat-end to floor distance, teat length and diameter of Gir cows according to milk flow: fast $\left(\mathrm{FF}>26.3 \mathrm{~mL} \mathrm{~s}^{-1}\right)$ or slow $\left(\mathrm{SF}<26.3 \mathrm{~mL} \mathrm{~s}^{-1}\right)$.

\begin{tabular}{lrrc}
\hline Parameters $(\mathrm{cm})$ & \multicolumn{1}{c}{ FF } & \multicolumn{1}{c}{ SF } & P \\
\hline Teat-end to floor & $47.22 \pm 0.19$ & $44.25 \pm 0.20$ & 0.07 \\
Teat length & $9.30 \pm 0.06$ & $10.40 \pm 0.07$ & 0.06 \\
Teat diameter & $3.78 \pm 0.03$ & $4.05 \pm 0.02$ & 0.16 \\
\hline
\end{tabular}

between small udders and low SCC. Moreover, deep udders, which imply in a low teat to floor distance, are related to higher SCC (Rogers et al., 1991; Faye et al., 1998) and with a higher risk of subclinical (Ronningen \& Reitan, 1990) and clinical (Slettbakk et al., 1995) mastitis occurrence.

Considering the ranges of SCC studied, no influence on milk yield and milk flow were observed $(\mathrm{p}>0.05)$ (Table 3). According to Sandrucci et al. (2007), a longduration milk flow has a positive correlation with SCC. This correlation was observed for either individual quarter or whole udder (Dodenhoff et al., 1999; Tancin et al., 2002). This relation is mainly linked to the unnecessary increase of time that the machine takes to perform milking, causing edema and influencing the health condition of teats (Hillerton et al., 2002).

Prevalence of the mastitis-causing agents was evaluated for each type of microorganism isolated in milk samples, and also for pathogen group: major and minor pathogens (Table 4). The type of mastitis-causing organism did not affect milk yield and milk flow ( $>0.05$ ). However, infected quarters with $S$. aureus and Corynebacterium spp. had higher log SCC (5.30 and 5.15 , respectively) compared with uninfected quarters (4.48). However, when classified by group, major pathogens were more frequently isolated in

Table 3. Means ( \pm standard error) of milk yield and milk flow in relation to somatic cell count (SCC).

\begin{tabular}{|c|c|c|c|c|}
\hline \multirow[t]{2}{*}{ Parameters } & \multicolumn{3}{|c|}{$\mathrm{SCC} \times 10^{3}$ cells $\mathrm{mL}^{-1}$} & \multirow[t]{2}{*}{$\mathrm{P}$} \\
\hline & $<200$ & 200 to 300 & $>300$ & \\
\hline Milk yield $\left(\mathrm{L} \mathrm{day}^{-1}\right)$ & $6.87 \pm 0.02 \mathrm{a}$ & $7.26 \pm 0.18 \mathrm{a}$ & $6.48 \pm 0.04 \mathrm{a}$ & 0.44 \\
\hline Milk flow $\left(\mathrm{mL} \mathrm{s}^{-1}\right)$ & $25.88 \pm 0.17 \mathrm{a}$ & $24.75 \pm 0.16 \mathrm{a}$ & $26.45 \pm 0.24 \mathrm{a}$ & 0.95 \\
\hline
\end{tabular}

Table 4. Isolation and pathogen type by mammary quarter and means of milk yield, milk flow and somatic cell count $(\mathrm{SCC})^{(1)}$.

\begin{tabular}{|c|c|c|c|c|}
\hline Isolations & Mammary quarter $(\%)$ & Milk yield $\left(\mathrm{L} \mathrm{day}^{-1}\right)$ & Milk flow $\left(\mathrm{mL} \mathrm{s}^{-1}\right)$ & Log SCC (cells mL $\left.\mathrm{m}^{-1}\right)$ \\
\hline Staphylococcus aureus & 25.22 & $7.41 \pm 0.04 \mathrm{a}$ & $27.65 \pm 0.35 \mathrm{a}$ & $5.30 \mathrm{a}$ \\
\hline Corynebacterium spp. & 14.22 & $6.27 \pm 0.08 \mathrm{a}$ & $23.81 \pm 0.49 a$ & $5.15 \mathrm{a}$ \\
\hline Coagulase-negative staphylococci & 18.34 & $6.26 \pm 0.05 \mathrm{a}$ & $24.20 \pm 0.27 \mathrm{a}$ & $5.00 \mathrm{ab}$ \\
\hline Others $^{(2)}$ & 5.98 & $7.60 \pm 0.20 \mathrm{a}$ & $24.81 \pm 0.20 \mathrm{a}$ & $5.00 \mathrm{ab}$ \\
\hline Negative & 36.24 & $6.68 \pm 0.02 \mathrm{a}$ & $27.87 \pm 0.64 \mathrm{a}$ & $4.48 \mathrm{~b}$ \\
\hline Major pathogens ${ }^{(3)}$ & 27.77 & $7.52 \pm 0.04 \mathrm{a}$ & $28.02 \pm 0.30 \mathrm{a}$ & $5.30 \mathrm{a}$ \\
\hline Minor pathogens ${ }^{(4)}$ & 36.99 & $6.32 \pm 0.02 b$ & $24.08 \pm 0.16 \mathrm{a}$ & $5.00 \mathrm{~b}$ \\
\hline
\end{tabular}


mammary quarters with higher milk yield and SCC $(\mathrm{p}<0.05)$.

In the studies of Schepers et al. (1997) and Riekerink et al. (2007), mammary quarters infected by major pathogens showed an increase of SCC greater than those infected by minor pathogens. According to Reneau (1986) this variation is associated with differences in the magnitude of cellular response and duration of intramammary infection.

\section{Conclusions}

1. Gir cows with longer teat canal have slow milk flow during milking.

2. Among the evaluated udder and teats morphometric characteristics, only the teat-end to floor distance is related to somatic cell counts (SCC) of Gir cows.

\section{Acknowledgements}

To Fundação de Amparo à Pesquisa do Estado de São Paulo, for financial support; and to Universidade de São Paulo, Agência Paulista de Tecnologia dos Agronegócios, Empresa de Pesquisa Agropecuária de Minas Gerais, and José Franchini Garcia Moreno support.

\section{References}

AYADI, M.; CAJA, G.; SUCH, X.; KNIGHT, C.H. Use of ultrasonography to estimate cistern size and milk storage at different milking intervals in the udder of dairy cows. Journal of Dairy Research, v.70, p.1-7, 2003.

BRUCKMAIER, R.M.; BLUM, J.W. B-mode ultrasonography of mammary glands of cows, goats and sheep during alpha- and beta-adrenergic agonist and oxytocin administration. Journal of Dairy Research, v.59, p.151-159, 1992.

CHRYSTAL, M.A.; SEYKORA, A.J.; HANSEN, L.B. Heritabilities of teat end shape and teat diameter and their relationships with somatic cell score. Journal of Dairy Science, v.82, p.2017-2022, 1999.

COBAN, O.; SABUNCUOGLU, N.; TUZEMEN, N. A STUDY ON RELATIONSHIPS BETWEEN SOMATIC CELL COUNT (SCC) AND SOME UDDER TRAITS IN DAIRY COWS. Journal of Animal and Veterinary Advances, v.8, p.134-138, 2009.

DJABRI, B.; BAREILLE, N.; BEAUDEAU, F.E.; SEEGERS. H. Quarter milk somatic cell count in infected dairy cows: a meta-analysis. Veterinary Research, v.33, p.335-357, 2002.

DODENHOFF, J.; SPRENGEL, D.; DUDA, J.; DEMPFLE, L. Studies on genetic evaluation of udder health using LactoCorder. Zuchtungskunde, v.71, p.459-472, 1999. FAYE, B.;
PEROCHON, L.; DORR, N.; GASQUI, P. Relationship between individual-cow udder health status in early lactation and dairy cow characteristics in Brittany, France. Veterinary Research, v.29, p.31-46, 1998.

HILLERTON, J.E.; PANKEY, J.W.; PANKEY, P. Effect of over-milking on teat condition. Journal of Dairy Research, v.69, p.81-84, 2002.

KLEIN, D.; FLOCK, M.; KHOL, J.L.; FRANZ, S.; STÜGER, H.P.; BAUMGARTNER, W. Ultrasonographic measurement of the bovine teat: breed differences and the significance of the measurements for udder health. Journal of Dairy Research, v.72, p.296-302, 2005.

KUCZAJ, M. Analysis of changes in udder size of high yielding cows in subsequent lactations with regard to mastitis. Electronic Journal of Polish Agricultural Universities, v.6, p.2-5, 2003.

MADALENA, F.E.; TRIVEDI, K.R. Experience with performance recording of dairy cattle in Brazil. International Committee for Animal Recording, Technical Series, v.1, p.235-246, 1998.

NATIONAL MASTITIS COUNCIL. Laboratory handbook on bovine mastitis. Madson: NMC, 1999. 222p.

NAUMANN, I.; FAHR, R.D.; LENGERKEN, G. Relationship between somatic cell count of milk and special parameters of milk flow curves of cows. Archives of Animal Breeding, v.41, p.237-250, 1998 .

NORMAN, H.D.; POWELL, R.L.; WRIGHT, J.R.; CASSELL, B.G. Phenotypic and genetic relationship between linear functional type traits and milk yield for five breeds. Journal of Dairy Science, v.71, p.1880-1896, 1988.

PAULRUD, C.O.; RASMUSSEN, M.D. How teat canal keratin depends on the length and diameter of the teat canal in dairy cows. Journal of Dairy Research, v.71, p.253-255, 2004.

PÉREZ-GUZMAN, M.D.; CLAUS, J.; JUNGE, W.; KALM, E. Studies on milkability and udder health in cattle. I. Verifying the relationship between milk flow and udder health. Zuchtungskunde, v.58, p.21-31, 1986.

PORCIONATO, M.A.F.; NEGRÃO, J.A.; LIMA, M.L.P. Produção de leite, leite residual e concentração hormonal de vacas Gir $\times$ Holandesa e Holandesa em ordenha mecanizada exclusiva. Arquivo Brasileiro de Medicina Veterinária e Zootecnia, v.57, p.820-824, 2005.

PORCIONATO, M.A.F.; NEGRÃO, J.A.; PAIVA, F.A. Morfometria e distribuição de leite alveolar e cisternal na glândula mamária de vacas Holandesa e Girolanda. Arquivo Brasileiro de Medicina Veterinária e Zootecnia, v.61, p.287-292, 2009.

RENEAU, J.K. Effective use of dairy herd improvement somatic cell counts in mastitis control. Journal of Dairy Science, v.69, p.1708-1720, 1986.

RIEKERINK, R.G.M.O.; BARKEMA, H.W.; VEENSTRA, W.; BERG, F.E.; STRYHN, H.; ZADOKS, R.N. Somatic cell count during and between milkings. Journal of Dairy Science, v.90, p.3733-3741, 2007.

ROGERS, G.W.; HARGROVE, G.L.; LAWLER JUNIOR, T.J.; EBERSOLE, J.L. Correlations among linear type traits and somatic cell counts. Journal of Dairy Science, v.74, p.1087-1091, 1991. 
RONNINGEN, O.; REITAN, A.D. Influence of static and dynamic teat characteristics and milking time on udder health in Norwegian Red cattle. Journal of Dairy Research, v.57, p.171-177, 1990.

SANDRUCCI, A.; TAMBURINI, A.; BAVA, L.; ZUCALI, M. Factors affecting milk flow traits in dairy cows: results of a field study. Journal of Dairy Science, v.90, p.1159-1167, 2007.

SAS INSTITUTE. SAS/STAT software changes. Version 8.2. Cary: SAS Institute, 2001.

SCHEPERS, A.J.; LAM, T.J.G.M.; SCHUKKEN, Y.H.; WILMINK, J.B.M.; HANEKAMP, W.J.A. Estimation of variance components for somatic cell counts to determine thresholds for uninfected quarters. Journal of Dairy Science, v.80, p.1833-1840, 1997.

SCHUTZ, M.M.; PAJOR, E.A. Genetic control of dairy cattle behavior. Journal of Dairy Science, v.84, p.31-38, 2001.

SHOOK, G.E. Selection for disease resistance. Journal of Dairy Science, v.72, p.1349-1362, 1989.

SILVA, E.C.L. da; MODESTO, E.C.; AZEVEDO, M. de; FERREIRA, M. de A.; DUBEUX JÚNIOR, J.C.B.; SCHULER, A.R.P. Efeito da disponibilidade de sombra sobre o desempenho, atividades comportamentais e parâmetros fisiológicos de vacas da raça Pitangueiras. Acta Scientiarum. Animal Sciences, v.31, p.295-302, 2009.
SLETTBAKK, T.; JØRSTAD, A.; FARVER, T.B.; HOLMES, J.C. Impact of milking characteristics and morphology of udder and teats on clinical mastitis in first- and second-lactation Norwegian cattle. Preventive Veterinary Medicine, v.24, p.235-244, 1995.

SOUZA, E.M.; MILAGRES, J.C.; REGAZZI, A.J.; MARTINEZ, M.L.; SILVA, M.A. e. Effects of genetic and environmental factors on milk production of dairy Gir cattle in Brazil. Revista da Sociedade Brasileira de Zootecnia, v.25, p.889-901, 1996.

TANCIN, V.; BRUCKMAIER, R.M. Factors affecting milk ejection and removal during milking and suckling of dairy cows. Veterinary Medicine - Czech, v.46, p.108-118, 2001.

TANCIN, V.; IPEMA, A.H.; HOGEWERF, P. Interaction of somatic cell count on quarter milk flow patterns. Journal of Dairy Science, v.90, p.2223-2228, 2007.

TANCIN, V.; IPEMA, A.H.; HOGEWERF, P.; GROOT KOERKAMP, P.; MIHINA, S.; BRUCKMAIER, R.M. Milk flow patterns at the end of milking at the whole udder or quarter levels: relationship to somatic cell counts. Milk Science International, v.57, p.306-309, 2002.

THOMAS, C.S.; SVENNERSTEN-SJAUNJA, K.; BHOSREKAR, M.; BRUCKMAIER, R.M. Mammary cisternal size, cisternal milk and milk ejection in Murrah buffaloes. Journal of Dairy Research, v.71, p.162-168, 2004.

Received on July 23, 2010 and accepted on November 3, 2010 